Click www.researchjournal.co.in/online/subdetail.html to purchase.

Volume 5 | Issue 2 | September, 2014 | 184-196 — e ISSN-2231-6434 |

International Research Journal of Agricultural Economics and Statistics

Visit Us - www.researchjournal.co.in $\mathbf{D}$ DOI : 10.15740/HAS/IRJAES/5.2/184-196

\title{
Research Paper Correlation studies for site specific nutrient management to achieve the target yields in sugarcane
}

B.T. NADAGOUDA AND S.M. HIREMATH

ABSTRACT : A field experiment was carried out to study the precision nutrients management in sugarcane during 2008-09 and 2009-10 at Research and Development Farm NSSK, Krishna Nagar, Dt. Bijapur. The experiment in farmers field extended to 2010-11 as only preliminary studies were conducted during 2008-09. The results revealed that the large yield variations in grids of uniformity trial $(82.7 \mathrm{t} / \mathrm{ha}-128.2 \mathrm{t} / \mathrm{ha}) 45.5 \mathrm{t} / \mathrm{ha}$ and nutrients uptake by the crop ranged between $148.9-547.4 \mathrm{~kg} \mathrm{~N} / \mathrm{ha}(398.5), 2.48-15.61 \mathrm{~kg} \mathrm{P} / \mathrm{ha}(13.13)$ and $124.8-434.2$ $\mathrm{kg} \mathrm{K} / \mathrm{ha}$ (309.4). Sugarcane plant crop recorded significantly higher yield (139.7 t/ha) in relatively high nitrogen containing soils over the low soil nitrogen containing groups (119.0 t/ha). Similar observations were recorded in growth and yield parameters of sugarcane. Ratoon sugarcane also recorded significantly higher yield in relatively high soil nitrogen containing group (126.2 t/ha) over the soils with low nitrogen (109.4 t/ha). Similar observations were recorded in growth and yield parameters.

KEY WORDS : Sugarcane, Correlation studies, Target yield, SSNM GPS

HOW TO CITE THIS PAPER : Nadagouda, B.T. and Hiremath, S.M. (2014). Correlation studies for site specific nutrient management to achieve the target yields in sugarcane. Internat. Res. J. Agric. Eco. \& Stat., 5 (2) : 184-196 